\title{
Scoring Rubric as the Authentic Assessment Used by the English Teachers to Run the National Curriculum in South Sumatera, Indonesia
}

\author{
Elsina Sihombing \\ Universitas Batanghari \\ Jambi- Indonesia \\ pures_elf@yahoo.com
}

\author{
Jufrizal \\ English Department \\ Faculty of Languages and Arts \\ Universitas Negeri Padang \\ juf ely@yahoo.com
}

\author{
Syafri Anwar \\ Geography Department \\ Faculty of Social Science \\ Universitas Negeri Padang \\ Syafri.anwar.fis@gmail.com
}

\begin{abstract}
Dealing with K-13 curriculum, one main point that makes it differs from other is one of its element, it is measurement standard, using authentic assessment. Authentic assessment recommends Contextual Teaching and Learning (CTL) as one of the methods of learning at schools. Contextual learning is a concept of learning in which the teacher help the students to parallelize the content of learning to the real context around the society and togetherly tailoring the knowledge to the students so that they can actualize it in daily life, see (Depdiknas, 2013). Language authentic assessment emphasizing on the language production ability more than theory only (linguistics competence) in daily communication to meet various needs of the students. Since most of the teachers especially in Lubuklinggau South Sumatera are still unfamiliar with authentic assessment( based on the preliminary study by the researcher), therefore, it is important to familiarize them so as to enable them in assessing the learners authentically and properly, especially in English. The result of her research is remaining that authentic assessment indicates the measurement of the learners learning with the competence based in doing something related to the themes they learned. The power of competence is not on the knowledge they have mastered but on the learners ability to present along the process, demonstrate, or doing something instead, as the result of the knowledge essence they have, meaningful and is needed around the environment.Language learning basically conditioning the parallelism of the three golden roots of learning; achievable competence, content and strategy, and learning evaluation.
\end{abstract}

Keywords- Scoring rubric, Authentic Assessment, National curriculum ( K-13 )

\section{INTRODUCTION}

The improvement of Indonesia curriculum in the last ten years becomes the trendy and booming topic to be discussed and overwhelmed doe to Indonesia educational condition, which never being unstoppable to improve. In such maneuver, the teachers are the subject or the agent and as the directing designer in the educational field, to moderate all things dealing with the education. As a matter of fact, in every maneuver of the curriculum, the teachers are certainly heading up to the goal or objective of every running curriculum. Different curriculum period needs different goals or objectives, and of course different content, see zais( 1996 ). This condition can influence the teacher steadiness to run the changing goals, from K-13 to KTSP and back to K-13 (revision) each in a short period. It makes all the teachers being confused and do not know what to do to fulfill what the last curriculum (K-13 revision) absorbs to, especially dealing with assessment and evaluation. They have known that K-13 is empowered with its specific assessment system, but they do not know what the elements of authentic assessment are, to be done.

Based on the idea of Reigeluth (2009), scoring rubric is the essential part of assessment of which the teachers measure the students achievement during their learning, and actualizing it in the form of written score and / or description as the formal report to the students' parents as the school's stakeholders. In this study, there are seven segments as the content of the model that will be developed throughout the authentic assessment of scoring rubric, they are: Behavior assessment, Product assessment, selfassessment, and peer- assessment, portfolio, project, and written test as reliable and valid instrument of evaluation, particularly suitable for assessing the real achievement based on the real life, and are also suggested by Reigeluth (2009). These reflective models encourage students to become involved in their learning, and promote positive attitude change in the fostering of life-long learning skills and socially responsible citizens.

\section{DISCUSION}

A. The Concept of Authentic Assessment

The purpose of this research is promoting the new simple solid way of implicating the developed model of authentic assessment based on the K-13 curriculum by developing the conventional authentic assessment, which is named as English authentic assessment, as a guidebook for the teachers. This model is called authentic since it covers all the representative segments to what the assessment intents to measure towards the learners in accordance with the context of life. Johnson \& Johnson (2002) suggest that for the purpose of the meaningful assessment there are some hints that should be followed, they are : 1) what students performances can be assessed 2) the procedures of the assessment. 3)the purpose of the assessment. 4) the focus 
of the assessment. 5)the setting of the assessment ( artificial or authentic). 6)the stakeholders involved in the assessment. 7)the procedures of the evaluation.

Based on the experts' perspectives above, the researcher raises an idea that Assessment should provide multiple measures and opportunities for students to create and demonstrate what they can do with a language. To provide a comprehensive picture of a student's language ability, the teacher should strive to create a balance between formative and summative assessments. Assessments should be authentic and include alternative and integrated performance-based assessments (performance assessment is also called authentic assessment, alternative assessment, and performance testing).Performance-based assessment is characterized by diagnostic measurement, which identifies the learners' strengths and weaknesses, (see Joyce, at al, 2003). Diagnostic test usually focuses on the low end of the achievement and provide a detailed frame of the students' level of performance that refers to authenticity of learning. These characteristics are in the same bold with what the K-'13 curriculum emphasizing on assessment, they are Minimum Mastery Criterion (MMC) as the low end of the achievement, detailed description of achievement, and remedial treatment for the students whose scores are under MMC, till they master the indicators, the goals, and the standard competence that are capsulated in the MMC they ought to pass in the assessment, ( see BSNP, 2010 ).Authentic assessment, in contrast to more traditional assessment, encourages the integration of teaching, learning and assessing.

In response to a prompt, students construct an answer out of old and new knowledge. Since there is no one exact answer to these prompts, students are constructing new knowledge that likely differs slightly or significantly from that constructed by other students. Typically, constructed response prompts are narrowly conceived, delivered at or near the same time a response is expected and are limited in length.Since assessment is a means of process evaluation, it is ongoing process of measurement dealing with the learners' learning during their period of study. According to Santrock (2007) that in the 1990s there were many efforts to employee performance or authentic measures, of which the learners were required to demonstrate their achievement by producing authentic responses to evaluation tasks such as written and spoken answers, musical or psychomotor presentation, portfolios of work product, or group solutions to defined problems. The purpose of this authenticity is to make the students to master bold understandings.It is also generalized by Stufflebeam that a process of assessment is an ongoing examination on a plan implementation and documentation of the process, that aims to remains feed back and improvement, see Stufflebeam (2007 ; 341). By using this feedback, the teacher is always forwarding to the next feedbacks during the process in running the program of instruction and skills and effectively apply them in real-life situations. Moreover, meaningful learning class can be earned if there is a context of learning how to learn to take every new information becomes meaningful, it is also sounding by the other experts, see Maslow (1984).

On the other hand, Carl Rogers ( 1987 ) develop self-actualization of Maslow by emphasizing intrinsic motivation to gain self competence to actualize himself in the real life.

Regarding to this study, Rogers characterizes learning principle by ; 1) Will of learning, 2) Meaningful learning, 3) Threatless in learning, 4) Self- initiative learning and the last, 5) Learning and changing. The topics which are in students' need might strengthen the learners to learn how to learn since they become meaningful topic to achieve, this is the real meaningful learning. In such a circumstance, the learners learn free-all out without under-pressure, threat, and punishment since learning flows from the learner's self-initiative which is comes purely from their own will. The real meaningful learning is the process oriented learning as the authenticity, of which the learners as the subject of the process, see Rogers ( 1987 ).

K-13 curriculum recommends the use of an approach, it is Contextual Teaching and Learning (CTL), for public schools in Indonesia. Contextual Learning is a concept of which the teacher links the material of learning to the real daily social life and mediating or scaffolding the learners to actualize the received knowledge into a meaningful learning in the real life, as well (Depdiknas 2013). This approach is holistic and integrated nurturing the learners pursuing their learning activity heading to the real life in the society.

Shortly, this approach emphasizes the importance of the linkage of learning material to be actualized in daily life of society, of which they are as a part (Maslow 1996)). In such a condition, it is hopefully there is a balance between what has been learned at school and the usage in the real life. At school, the learners are scaffolded to build a linkage of new information to the prior information, how to learn a concept and how the concept is actualized in real daily life. Since the contextual learning is the process of inquiry which engage teachers and learners roles to promote the information linked to the real life of the learners world without any manipulation and purely happens to meet the learners need, the teachers function is not purely only for teaching but for educating the learners, as well. According to Elaine B. Johnson (2002)

contextual teaching and learning (CTL) is an educational process that makes the learners to correlate between the content to the context of daily life. Regarding the theories above, the writer believe that the more fresh experiences given to learners, the more active their brain to form new correlation to gain new meaningful learning. In every ending of the learning process, to measure the learners achievement, it is certainly should be assessed authentically as emphasizing by K-13 curriculum. It is also supported by Depdiknas (2003), that contextual teaching and learning is a learning concept that help the teacher to bridge the content to the real condition of daily life and motivate the learners to order their prior knowledge as the basis of the next experiences in their real world. Based on the perspectives above, the researcher believes that throughout the authentic assessment the teachers and the learners can breakthrough the limit of learning during the process to gain the fruits of learning to actualize in their life. 
The proper technique of measuring of CTL is authentic assessment. This technique emphasizes the measurement of the learners competency in doing something (performance), process - orientation rather than product - orientation. The fundamental gain is not only merely at the cognitive but also at the learners performance of how to present, to demonstrate, or to do something due to essential knowledge they have mastered. Overall, demonstrating the mastered competencies is not merely for the purpose of the knowledge itself, but much more important is grabbing it and actualize the reality as a need in daily life.

Therefore, in authentic assessment, the learners competence is measured through out their ability to show up the knowledge, performance, and attitude on the basis of meaningful learning (Mueller, 2008). The term meaningful has a fundamental correlation with daily life, so it is reasonable to give the chance for the learners to demonstrate their competencies in each of the measurement that the teacher conduct against the learners.

To meet the learners need in learning, the teacher should always run various instructional methods of teaching to drill the learners and assessing them as well, to never being neglected or loss the students academic track during the process in the three domains of learning, namely ; Affective, Psychomotor, Cognitive.

The writer found that previous curriculum lacks of technique of evaluation in continuum, especially in English subject, it was un-contextual assessment (emphasizing paper/pencil test), instead of authentic assessment. In authentic assessment, there is a balance among the triangle parts ; competence, content, assessment.

Generally, the objective of Learning English at school as a foreign language in indonesia is to obtain the ability in communication throughout the four skills. Therefore, English assessment should be in a parallelism line with the objective, that is authentic assessment for authentic learning. In other words, assessing language is not only assessing the ability of language knowledge (linguistic) but also the ability of verbal language (communication). Since most of the teachers are still unfamiliar with authentic assessment and said that the components to measure are in doubt, too many components and the assessment itself takes much time to do, with such a reason many teachers are hesitate to run it and some pay no attention as the impact of the negative rumor about authentic assessment which said that it is very complicated and messy, takes much time to do. This reason, inspiring the researcher to save the condition and help the teachers to lean upon the rumor and familiarize them with an easy simple compact applicable English blended assessment model.

Therefore, it is reasonable to say that authentic assessment model is necessary and as a compulsory task for the teachers, instead. It can improve the quality of learning and raising a meaningful learning and supporting the implication of K-13 as the latest and updated curriculum in Indonesia.

\section{B. The Concept of Scoring Rubric}

In K-13, it is defined that authentic assessment is the process of gathering and analyzing information about the students for the purpose of measuring learners achievement during the process of learning in continuum, see (Permendikbud no. 23, 2016). In these rules, the Government in the minister of education's written decision briefly stated that type of assessment for primary, secondary, and Senior High schools is authentic assessment by implementing scoring rubric.Scoring rubric involving both numeric and description to measure the 3 domains; affective, cognitive, and Psychomotor. Scoring the learners achievement should be in criterion-based which is termed as KKM (KriteriaKetuntasan Minimal) or MMC (Minimal Mastery Criterion). The MMC is standardized by the subject teachers for each of the grades in a school at every beginning of academic year, and is implacable in continuum. Other characteristics of scoring rubric based on K-'13 are : scoring and learning content is integrated one each other and encapsulated in a unity of curriculum, opened-minded for all the stakeholders in the school, prefer process oriented instead of product oriented, systematic, accountable, and criterion-reference.

Based on Permendikbud (2016; chapter IV; verse 6) scoring procedures covering the 3 domains: 1) Attitude. It can be measured by conducting an observation, record it academically, and the result is prescribed in description form. 2) Knowledge. It can measured by paper/pencil test (product) or by observing during the process (performance), and the result is prescribed in numerical range $(0-100)$. 3) Psychomotor. It can be measured throughout the process and product assessment, scoring it in numerical range and description. All those three domains are captured and blended in scoring rubric to produce a valid and accountable qualification of the learners to show how far meaningful learning is tailored and reversely, how well-tailored the learners are.

Authentic assessment is similar with Performance-based assessment, it is characterized by diagnostic measurement, which identifies the learners' strengths and weaknesses, (see Joyce, at al, 2003). Diagnostic test usually focuses on the low end of the achievement and provide a detailed frame of the students' level of performance that refers to authenticity of learning. These characteristics are in the same bold with what the K-13 curriculum emphasizing on assessment, they are Minimum Mastery Criterion (MMC) as the low end of the achievement, detailed description of achievement, and remedial treatment for the students whose scores are under MMC, till they master the indicators, the goals, and the standard competence that are encapsulated in the MMC they ought to pass in the assessment, ( see BSNP, 2010 ).

In this study, there are seven segments as the content of the model that will be developed throughout the authentic assessment of scoring rubric, they are :Behavior assessment, Product assessment, self- assessment, and peer- assessment, portfolio, project, and written test as reliable and valid instrument of evaluation, particularly suitable for assessing the real achievement based on the real life, and are also suggested by Reigeluth (2009). These reflective models encourage students to 
become involved in their learning, and promote positive attitude change in the fostering of life-long learning skills and socially responsible citizens. It is suggested, therefore, that when employing in a student-centered class, holistic setting, self- and peerassessment are practical and effective evaluation tools to obtain a meaningful product of learning for senior high or tertiary language education.

Product of learning can not be well-done without a planning and process, but those three are a unity in a cycle. The researcher, firstly suggested the teachers to prepare their planning by completing the table below.

Table 1. Teachers' Preparation

\begin{tabular}{|c|c|c|}
\hline When Executed & Type of Decision & Specific Activities \\
\hline \multicolumn{3}{|c|}{ Planning Phase } \\
\hline Pre-Implementation & $\begin{array}{ll}\text { 1. } & \text { Outside to be achieved } \\
\text { 2. } & \text { Courses of action to be taken }\end{array}$ & \\
\hline \multicolumn{3}{|c|}{ Process Phase } \\
\hline During Implementation & $\begin{array}{l}\text { 1. Degree to which execution is taking } \\
\text { place as planned } \\
\text { 2. Changes needed for the shake of } \\
\text { improvement }\end{array}$ & $\begin{array}{ll}\text { 3. } & \text { Situation analysis } \\
\text { 4. } & \text { Specification of objectives } \\
\text { 5. } & \text { Specification of prerequisite } \\
\text { 6. } & \text { Selection/development of measuring of } \\
& \text { instruments } \\
\text { 7. } & \text { Delineation of strategies } \\
\text { 8. } & \text { Selection of a design } \\
\text { 9. } & \text { Preparation of time schedule } \\
\end{array}$ \\
\hline \multicolumn{3}{|c|}{ Product Phase } \\
\hline Post Implementation & $\begin{array}{l}\text { 1. Overall effectiveness of the instruction, } \\
\text { project, or program } \\
\text { 2. Future courses of action }\end{array}$ & $\begin{array}{ll}\text { 1. } & \text { Collection of data pertinent to the objectives (e.g : posttest) } \\
\text { 2. Collection of data related to unanticipated } \\
\text { outcomes } \\
\text { 3. Analysis and interpretation of the data } \\
\text { 4. } \\
\text { Reporting. }\end{array}$ \\
\hline
\end{tabular}

C. The Product of Development

The product of the development is settled separately from this article in the form of a guide-book, which at the end of the research will distribute or disseminate to the teachers, to the national education department of Lubuklinggau city, and the chairman of Lubuklinggau city. The model of development is adapted and developed from R2D2-model (by Willis 2000). At the first time, R2D2 model ( Recursive, Reflective, Design, and Development) is initiated to develop Instructional Design in teaching qualitative research subject by Willis in 1995, (see Willis, 2000). But in this study, the researcher develops this model toward research and development of authentic assessment, which at the end of the research, resulting a model of an authentic assessment that focusing on scoring rubric, which is valuable and helpful for the teachers especially English teachers.

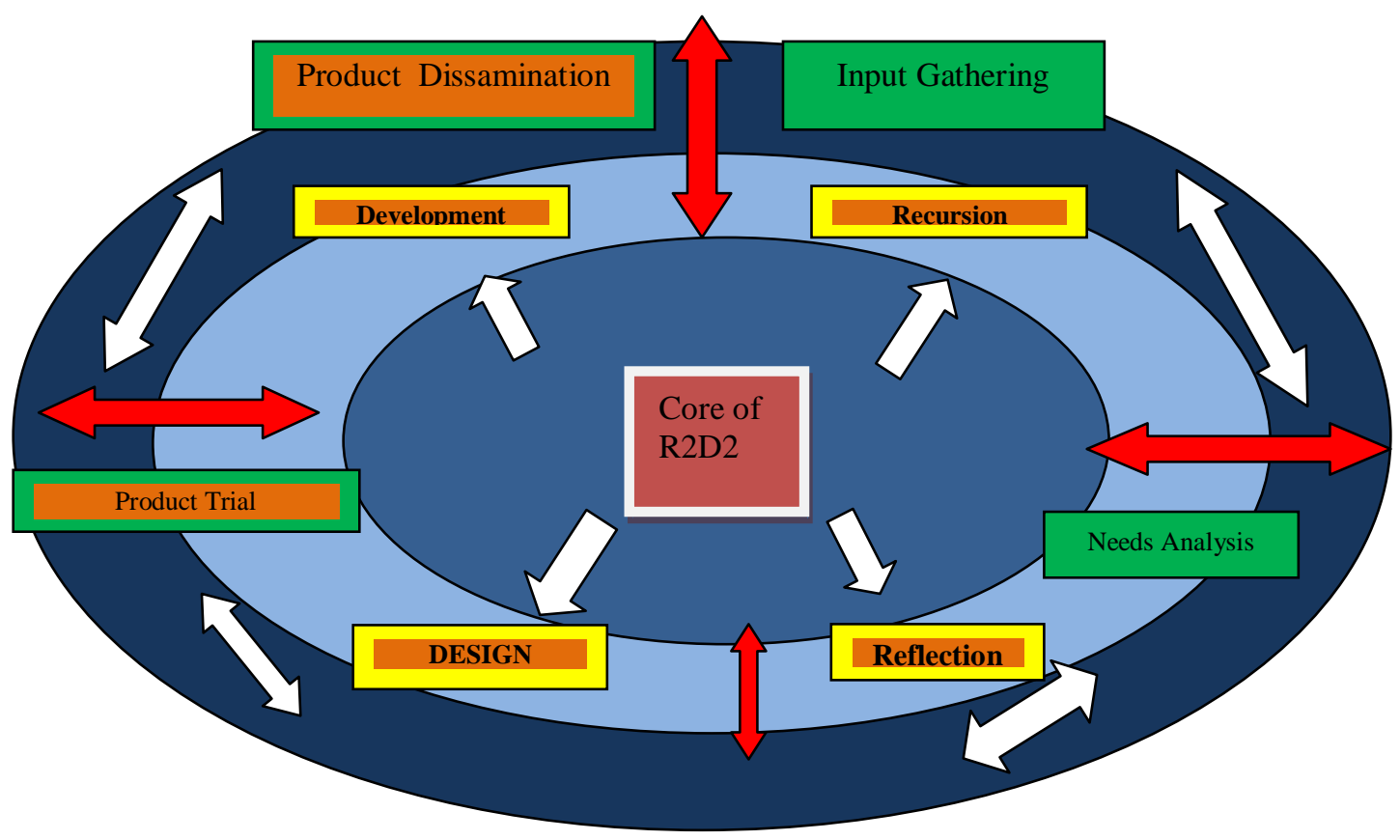

Fig. 1. Chart of Authentic Assessment Model Development 
The product of this study is a guide book of English Authentic Assessment Model that covers (a) assessment planning, (b) assessment specification, (c) assessment rubrics, (d) evaluation standard, and (e) final score. To help the teachers implementing the authentic assessment easily, the product of this research will be completed with a VCD containing with its implementation model.

\section{CONCLUSION}

This research belongs to Mixed Research focusing on Concurrent Triangulation. In conducting such a type, the starting point is by carrying out both the methods together namely qualitative and quantitative due to the research problems and the objectives of the research methods.

It is found that authentic assessment using scoring rubric is fundamentally help the English teachers to measure the students achievement of learning reasonably, which means that no score subjectively based on the teachers' feeling but should be based on the standard of rubric, instead.

The last principle, Development, is based on the assumption that the context of use is critically important. Further, the people most familiar with those contexts will be the users, after the researcher conducts a need analysis and meets kinds of demands that the English teachers really need in the school. In R2D2 the idea of participatory design has been expanded beyond end users to include "experts". Thus, in this research the R2D2 design model involves a participatoryteam that guides the process. This team typically includes instructional designers (in this case the researcher), subject matter experts, teachers, and students. Members of the team are often referred to as stakeholders.

\section{Guiding Syntax}

a. doing a preliminary study dealing with the research problem

b. treasuring the preliminary data to find needs of the stakeholders in the schools

c. designing the frame of work, what to do during research conduction, structuring a group discussion forum (GDF) as the validation team..

d. running-down the design of works and controlling the way of what and how to do.

Data collection in this study is Nominal and ordinal data resources from both qualitative and quantitative data, since this research belongs to mixed method research focusing on Concurrent triangulation strategy, of which the quantitative method is embedded in the qualitative one.The data are enriched by triangulation technique, it means that both qualitative and quantitative data will be collected by means of (1) interview, (2) questionnaire, (3) observation and documentation.

\section{References}

Ansyar, Mohammad. 2014. Kurikulum( Hakikat, Fondasi, disain \&Pengembangan). Jakarta. Penerbit Kencana Prenada media Group.

Bloxham\& Boyd. 2007. Developing Effective Assessment in Higher Education. New York. Open Univ. Press.

Boundless.Maslow's Theory in Boundless Psychology.https://www.boundless.com/psychology/textbooks/boundless-psychology. retrieved by June 18th, 2016.

Burns, Robert. 1995. Research Method. Australia. Longman Australia Ptd, Ltd.

Field, Andi. 2005. Discovering Statistics Using SPSS. London. Sage Publication.

Frankle\&Wallen. 1993. How To Design and Evaluate Research. New York. McGraw-Hill Inc.

Gay, L.R. 1980. Educational Evaluation \& Measurement. London. Charles E. MERRIL Publishing Company.

Gay \&Airasian. 2000. Educational Research. Ohio. Prentice Hall, Inc.

Jackendoff, Ray. 2003. Foundation of Language. New York. Oxford University Press.

Johnson \& Johnson. 2002. Meaningful Assessment. Sydney. Allyn\& Bacon Company.

Joyce \& Weil. 1992. Models of Teaching. London. Allyn and Bacon Publication.

Ken, Springer. 2010. Educational Research. New York. John Wiley \& Sons, Inc.

Mori \& Tanabe. 2015. Influence of Instructor Personality on Student Evaluation of Teaching. English Language Teaching;

Vol. 8, No. 1. URL: http://dx.doi.org/10.5539/elt.v8n1p1.

Retrieved by : December 17, 2014.

Naga, Dali S. 1992. TeoriSekor. Jakarta. Gunadarma Press.

Ormrod, Jeanne. 2009. PsikologiPendidikan. Jakarta. PT.GeloraAksaraPratama.

Ornstein \&Hunkins. 2013. Curriculum. Boston. Allyn and Bacon Publication.

PeraturanPemerintah RI No. 17. DelapanStandarNasionalPendidikan. Jakarta. PT. Binatama Raya.

Popham, James. 1975. Educational Evaluation. New Jersey. Prantice-Hall Inc.

Reigeluth\&Chellman. 2009. Instructional Design Theories and Models. New York. Routledge Group.

Reiser\& Dempsey. 1997. Trends and Issues in Instructional Design and Technology. Ohio. Merill Prentice Hall.

Stufflebeam\&Shinkfield. 2007. Evaluation Theory, Models, \& Applications. United States. John Wiley \& Sons, Inc.

Sugiyono. 2010. PenelitianPendidikan. Bandung. Alfabeta. 
Willis, at al. 2000.Constructivist Instructional Design: Creating a Multimedia Package for Teaching Critical Qualitative Research. http://www.nova.edu/ssss/QR/QR5-1/colon.html).

Yan, Jiaolan at al. 2015. Research and Practice on College English Oral Test. Beijing. English Language Teaching; Vol. 8, No. 3. URL: http://dx.doi.org/10.5539/elt.v8n3p121. Retrieved by : February 13, 2015.

Yasin, Anas. 2012. PenelitianKualitatif :Etnografi, Fenomenologi. Padang. Bung Hatta University Press.

Yusuf, Muri. 2013. MetodePenelitian. Padang. UNP Press.

Zais, Robert. 1996. Curriculum Principles and Foundation. New York. Crowell Company, Inc. 